\title{
DESAIN PENGEMBANGAN PEMBELAJARAN PENDIDIKAN AGAMA ISLAM DI SEKOLAH DAN MADRASAH
}

\author{
Muhamad Tanthowi Jauhari \\ UIN Sunan Kalijaga Yogyakarta \\ asyazdily@gmail.com
}

\begin{abstract}
Models and learning strategies that override the structure of learning content so that the material delivered by the teacher, does not last long in students' memories. The purpose of this paper is to find out the steps in organizing, establishing, and developing strategies for organizing the contents of religious education learning through the design of professional Islamic religious education learning. Meanwhile, the theory used in this problem is to use the theory of learning design models that refer to the systems approach, which is developed by Kemp, Dick and Carey, and the Dageng model, all of which include analysis of learning conditions, development of learning strategies, and development of measurement procedures learning. This paper is a research type of library reaserch, which is descriptive analytical. The method of thinking in this paper uses the inductive method in which the discussion is to analyze data from facts that are specific to general facts about the design of the development of $P$ AI learning. The results of this paper study show that: (1) The design of the development of $P A I$ learning by using the Kemp model rests on four basic elements of learning planning, namely students, objectives, methods, and evaluation. The design model of Dick and Carey's development refers to the system approach and Degeng's development design model is based on variables that influence learning in the form of objectives and characteristics of the field of study, learning resources and constraints, learner characteristics, learning objectives and learning content, strategies for organizing learning contents, delivery strategies learning content, learning management strategies, developing learning outcomes measurement procedures. (2) The steps in the design of the development of PAI learning in schools and madrassas include: analysis of competency standards, learning materials, characteristics of students, selecting and defining approaches and evaluating learning outcomes.
\end{abstract}

Keywords: Learning Development Design, Islamic Education, School and Madrasa

\begin{abstract}
Abstrak : Model dan strategi pembelajaran yang mengenyampingkan struktur isi pembelajaran sehingga materi yang disampaikan guru, tidak bertahan lama dalam ingatan peserta didik. Tujuan dari makalah ini adalah mencari tahu langkah dalam menata, menetapkan, dan mengembangkan strategi pengorganisasian isi pembelajaran pendidikan agama melalui perancangan pembelajaran pendidikan agama Islam yang profesional. Sementara itu, Teori yang digunakan dalam permasalahan ini adalah menggunakan teori model disain pembelajaran yang mengacu pada pendekatan sistem, yakni yang dikembangkan oleh Kemp, Dick dan Carey, dan model Dageng, yang ketiganya mencakup analisis kondisi pembelajaran, pengembangan strategi pembelajaran, dan pengembangan prosedur pengukuran pembelajaran. Tulisan ini adalah penelitian pustaka (library reaserch) yang bersifat deskriptif analitis. Metode berpikir dalam tulisan ini menggunakan metode induktif yang dimana pembahasannya adalah dengan menganalisis data dari fakta yang bersifat khusus ke arah fakta yang bersifat umum mengenai desain pengembangan pembelajaran PAI. Hasil telaah makalah ini menunjukkan bahwa: (1) Desain pengembangan pembelajaran PAI dengan menggunakan model Kemp berpijak pada empat unsur dasar perencanaan pembelajaran, yaitu peserta didik, tujuan, metode, dan evaluasi. Model
\end{abstract}

Islamika : Jurnal Keislaman dan Ilmu Pendidikan

Volume 2, Nomor 2, Juli 2020; 328-341

https://ejournal.stitpn.ac.id/index.php/islamika 
desain pengembangan Dick dan Carey mengacu pada pendekatan sistem dan model desain pengembangan Degeng didasarkan pada variabel yang memengaruhi pembelajaran berupa tujuan dan karekteristik bidang studi, sumber belajar dan kendala, karakteristik peserta didik, tujuan belajar dan isi pembelajaran, strategi pengorganisasian isi pembelajaran, strategi penyampaian isi pembelajaran, strategi pengelolaan pembelajaran, pengembangan prosedur pengukuran hasil pembelajaran. (2) Langkah-langkah desain pengembangan pembelajaran PAI di sekolah dan madrasah antara lain: analisis strandar kompetensi, materi pembelajaran, karakteristik peserta didik, memilih dan menetapkan pendekatan dan menetapkan evaluasi hasil pembelajaran.

Kata Kunci: Desain Pengembangan Pembelajaran, Pendidikan Agama Islam, Sekolah dan Madrasah

\section{PENDAHULUAN}

Belajar hakikatnya adalah suatu proses yang ditandai dengan adanya perubahan pada diri seseorang. Perubahan sebagai hasil dari proses belajar dapat diindikasikan dalam berbagai bentuk seperti berubah pengetahuan, pemahaman, sikap, dan tingkah laku, kecakapan, ketrampilan dan kemampuan, serta perubahan aspek-aspek yang lain yang ada pada diri individu yang belajar. ${ }^{1}$

Dalam proses belajar mengajar tentunya berkaitan dengan pendekatan, metode pembelajaran dimana bisa kita sebut sebagai desain pembelajaran. Desain pembelajaran yang dibuat sedemikian rupa akan menentukan arah atau tujuan pembelajaran yang diharapkan mengingat di masa sekarang ini banyak sekali model-model pembelajaran yang lebih variatif yang digunakan guru dalam proses pembelajaran di kelas maupun di luar kelas. Namun dari model-model tersebut, terkadang mengenyampingkan struktur isi pembelajaran, sehingga pesan yang terdapat dalam materi pembelajaran kurang begitu mengena dalam benak peserta didik dan cenderung tidak bertahan lama dalam ingatan peserta didik.

Pendidikan Agama Islam (PAI) merupakan proses melatih, mengajar, dan menuntun siswa menjadi lebih baik agar berguna bagi diri untuk masa depannya di dunia dan di akhirat nantinya dan berguna bagi masyarakatnya serta dapat mengambil manfaat dari suatu kejadian atau peristiwa yang telah dialaminya untuk diambil hikmah dari setiap kejadian tersebut.

1 Trianto, Mendesain Model Pebelajaran Inovatif-Progresif: Konsep, Landasan, dan Implementasinya pada Kurikulum Tingkat Satuan Pendidikan (KTSP), (Jakarta: Kencana, 2010) hal. 9 
Tulisan ini akan membahas mengenai desain pengembangan pembelajaran model Kemp, Dick-Carey, dan Degeng, dan pengembangan pembelajaran PAI di sekolah dan madrasah. Sehingga ada dua rumusan masalah yang akan dijawab di dalam tulisan ini, yaitu. Pertama, Bagaimana desain pengembangan pembelajaran model Kemp, DickCarey, dan Degeng? dan Kedua, Bagaimana pengembangan pembelajaran PAI di sekolah dan madrasah?

\section{Desain Pengembangan Pembelajaran Model Kemp, Dick-Carey, dan Degeng}

Dalam pengembangan pembelajaran ada beberapa model desain pembelajaran yang mengacu pada pendekatan sistem, antara lain model yang dikembangkan Jerrold E. Kemp (1985), model Walter Dick dan Lou Carey (1985), model I Nyoman Sudana Degeng (1989), dan masih banyak lagi. Dalam mengembangkan pembelajaran PAI bisa menggunakan model-model yang ada, atau dengan memadukan atau suatu model sendiri. Penggunaan suatu model tidak bersifat panasea (serba cocok untuk segala kondisi pembelajaran). Pemilihan dan penerapan suatu model desain pembelajaran untuk mengembangkan pembelajaran PAI harus disesuaikan dengan kebutuhan pembelajaran PAI, kondisi pembelajaran PAI, dan hasil pembelajaran PAI yang diharapkan. Untuk menghasilkan suatu produk pembelajaran PAI, dengan diikuti langkah-langkah pengembangannya secara konsisten sehingga dapat menghasilkan produk pembelajaran PAI yang berkualitas. ${ }^{2}$

Berikut ciri-ciri umum model Kemp, model Dick dan Carey, dan model Degeng dalam desain pengembangan pembelajaran dapat dikemukakan sebagai berikut.

a. Model Kemp

1) Analisis kondisi pembelajaran, meliputi:

a) Perkiraan kebutuhan belajar (learning need)

b) Memilih dan menetapkan pokok bahasan atau tugas pembelajaran

c) Meneliti dan identifikasi karekteristik peserta didik

d) Menentukan isi pelajaran dan menguraikan tugas

e) Menyatakan tujuan khusus belajar

2 Muhaimin, Paradigma Pendidikan Islam: Upaya Mengefektifkan Pendidikan Agama Islam di Sekolah, (Bandung: PT. Remaja Rosdakarya, 2004), hal. 221. 
2) Pengembangan strategi pembelajaran, meliputi:

a) Merancang kegiatan belajar mengajar

b) Memilih media untuk mendukung kegiatan pengajaran

c) Merinci pelayanan penunjang untuk mengembangkan semua kegiatan

3) Pengembangan prosedur pengukuran hasil pembelajaran, meliputi:

a) Mengembangkan alat evaluasi hasil belajar dan hasil program prngajaran

b) Melakukan uji awal untuk memperoleh produk pembelajaran

b. Model Dick dan Carey

1) Analisis kondisi pembelajaran, meliputi:

a) Identifikasi tujuan umum

b) Analisis pembelajaran

c) Analisis karakteristik peserta didik

d) Merumuskan tujuan khusus

2) Pengembangan strategi pembelajaran, meliputi:

a) Mengembangkan butir tes

b) Mengembangkan strategi pembelajaran

c) Mengembangkan bahan pembelajaran

d) Merevisi bahan pembelajaran

3) Pengembangan prosedur pengukuran hasil pembelajran

a) Merancang dan elakukan evaluasi formatif

b) Merancang dan melakukan evaluasi sumatif

c. Model Degeng

1) Analisis kondisi pembelajaran, meliputi:

a) Menganalisis tujuan dan karakteristik bidang study

b) Menganalisis simber belajar dan kendalanya

c) Menganalisis karakteristik pelajar

d) Menetapkan tujuan belajar da nisi pembelajaran

2) Pengembangan strategi pembelajaran, meliputi:

a) Menetapkan strategi pengorganisasian isi pembelajaran

b) Menetapkan strategi penyampean isi pembelajaran

c) Menetapkan strategi pengelolaan pembelajaran 
3) Pengembangan prosedur pengukuran hasil pembelajaran

Mengadakan pengembangan prosedur pengukuran hasil pembelajran. ${ }^{3}$

Lebih lanjut, ciri-ciri khusus ketiga model tersebut dalam desain pengembangan pembelajaran dapat dikemukakan sebagai berikut.

a. Model Kemp

Desain pengembangan pembelajaran PAI dengan menggunakan model Kemp berpijak pada empat unsur dasar perencanaan pembelajaran yang merupakan jawaban atas pertanyaan:

1) Untuk siapa program itu dirancang? Peserta didik

2) Kemampuan apa yang ingin Anda pelajari? Tujuan

3) Bagaiamana isi pelajaran atau keterampilan yang dapat dipelajari? Metode

4) Bagaimana anda menentukan tingkat penguasaan pelajaran yang sudah dicapai? Evaluasi. $^{4}$

b. Model Dick dan Carey

Model desain pengembangan Dick dan Carey (1985) mengacu pada pendekatan sistem (system approach). Berbeda dengan pandangan tradisional bahwa proses pembelajaran meliputi guru, siswa, dan buku pelajaran. Isi yang harus dipelajari termuat di dalam buku pelajaran, dan menjadi tanggung jawab guru untuk mengajarkan isi tersebut kepada siswa. Mengajar dapat ditafsirkan sebagai satu kegiatan dalam memasukkan isi atau bahan dari buku ke kepala siswa dengan sedemikian rupa sehingga mereka dapat mengeluarkan kembali segala informasi untuk dites. Dengan pendekatan ini, cara memperbaiki pembelajaran adalah dengan jalan memperbaiki gurunya, yaitu meminta guru belajar lebih banyak pengetahuan, lebih banyak metode dan sebagainya yang semuanya terpusat pada guru (teacher centered). ${ }^{5}$

Dengan demikian, Desain pengembangan pembelajaran dengan pendekatan sistem artinya setiap komponen sistem menjadi satu kesatuan secara sistemis. ${ }^{6}$

${ }^{3}$ Maksudin, Pengembangan Metodologi Pendidikan Agama Islam Pendekatan Dialektik, (Yogyakarta: Pustaka Pelajar, 2015), hal. 144-146

4 Muhaimin, Paradigma Pendidikan .... hal. 222.

${ }^{5}$ Ibid., hal. 225

${ }^{6}$ Maksudin, Pengembangan Metodologi .... hal.146 
c. Model Degeng

Desain pengembangan pembelajaran didasarkan pada variabel yang memengaruhi pembelajaran berupa tujuan dan karekteristik bidang studi, sumber belajar dan kendala, karakteristik peserta didik, tujuan belajar dan isi pembelajaran, strategi pengorganisasian isi pembelajaran, strategi penyampaian isi pembelajaran, strategi pengelolaan pembelajaran, pengembangan prosedur pengukuran hasil pembelajaran. $^{7}$

Secara umum ketiga model pembelajaran tersebut memiliki kelebihan dan kelemahan. Kelebihannya secara umum ketiga model tersebut ialah berorientasi pada pengembangan pembelajaran yang berpusat pada peserta didik (pupil centered). Demikian juga, ketiga model tersebut memiliki kelemahan umum, yaitu pada setiap model tidak membahas pengaruh peran guru terhadap keberhasilan pembelajaran. Berikut ini dikemukakan kelebihan dan kelemahan masing-masing model tersebut.

1) Model Kemp

Model Kemp memiliki kelebihan yaitu bahwa variable-variabel yang berpengaruh pada pembelajaran disebutkan secara rinci sehingga mudah untuk dipraktekkan dalam pembuatan desain pengembangan pembelajaran. Di sisi lain, model ini tidak menyebutkan variabel apa yang dominan yang berpengaruh terhadap keberhasilan pembelajaran.

2) Model Dick dan Carey

Pada model Dick dan Carey konsep pengembangan desain pembelajran lebih lengkap dan komperhensip dan penekanannya dalam pnegembangan pembelajaran terletak pada pendekatan sistem. Namun demikian, pada model ini subsistem yang amat berpengaruh pada pencapaian hasil pembelajaran tidak tampak.

3) Model Degeng

Pada model Degeng konsep desain pengembangan pembelajaran bersifat sederhana atau singkat, sehingga mudah difahami oleh para guru. Namun

${ }^{7}$ Ibid., hal. 146 
demikian, di dalam model ini tidak tampak adanya hubungan antara keempat unsur secara sistemis.

\section{Desain Pengembangan Pembelajaran PAI di Sekolah dan Madrasah}

Berdasarkan tinjauan berbagai model desain pembelajaran yang telah dikemukakan di atas dan berdasarkan berbagai tinjauan atas kelebihan dan kelemahannya, formulasi desai pengembangan pembelajaran PAI diusulkan sebagai berikut.

Dengan perubahan ilmu, teknologi dan seni secara cepat berpengaruh terhadap kehidupan berbangsa, bernegara, bermasyarakat dan beragama. Hal ini menuntut adanya upaya di bidang pendidikan agama Islam untuk disempurnakan dan dikembangkan secara nasional berupa kurikulum dengan ciri-ciri sebagai berikut.

a. Lebih menitik beratkan pencapaian target kompetensi (attainment targets) daripada penguasaan materi

b. Lebih mengakomodasikan keragaman kebutuhan dan sumber daya pendidikan yang tersedia

c. Memberikan kebebasan yang lebih luas kepada pelaksana pendidikan di lapangan untuk mengembangkan dan melaksanakan program pembelajaran sesuai dengan kebutuhan. ${ }^{8}$

Untuk mewujudkan kurikulum yang mempunyai ciri tersebut diperlukan suatu model. Desain pengembangan pembelajaran bidang pelajaran pendidikan agama Islam untuk Skolah Menengah Umum 0.

Model-model desain pengembangan pembelajaran yang dapat digunakan dalam konteks ini adalah sebagai berikut.

Tahap pertama, definisi meliputi:

a. Analisis terget kompetensi (tujuan)

b. Analisis materi pembelajaran

c. Analisis karakteristik peserta didik

Tahap kedua, pengembangan sistem meliputi:

a. Memilih dan menentukan pendekatan

b. Memilih dan menentukan pengorganisasian

${ }^{8}$ Diknas," Kompetensi Dasar Mata Pelajaran Pendidikan Agama Islam SMU” dalam Maksudin, Pengembangan Metodologi Pendidikan Agama Islam Pendekatan Dialektik, (Yogyakarta: Pustaka Pelajar, 2015) hal. 148 
Tahap ketiga, evaluasi meliputi:

a. Evaluasi hasil belajar

b. Mengembangkan hasil evaluasi. ${ }^{9}$

Langkah-langkah Desain Pengembangan Pembelajaran PAI sebagai berikut.

a. Analisis Standar Kompetensi

Menganalisis standar kompetensi dimulai dari apa yang dimaksud kompetensi itu. Kompetensi merupakan kebulatan pengetahuan, keterampilan, dan sikap yang dapat didemonstrasikan, ditunjukkan, atau ditampilkan oleh peserta didik sebagai hasil belajar. Sesuai dengan pengertian tersebut, maka standar kompetensi adalah kemampuan standar yang harus dikuasai untuk menunjukkan bahwa hasil mempelajari bidang studi PAI atau mata pelajaran tertentu berupa penguasaan atas pengetahuan, sikap, dan keterampilan tertentu telah dicapai.

Dalam menganalisis standar kompetensi paling tidak terdapat dua masalah. Pertama berkaitan dengan cakupan, ruang lingkup, aspek, ranah, matra atau domain. Kedua berkaitan dengan kata kerja yang digunakan.

Kompetensi umum PAI untuk Sekolah Menengah Umum sebagai berikut:

1) Mampu membaca dengan mengetahui hikum bacaannya, menulis, dan memahami ayat Al-Qur'an serta mampu mengimplementasikan dalam kehidupan sehari-hari;

2) Beriman kepada Allah SWT, malaikat, kitab-kitab, rasul, hari kiamat, dan qadha qadar dengan mengetahui fungsi dan hikmahnya serta terefleksi dalam sikap, perilaku, dan akhlak peserta didik pada dimensi kehidupan sehari-hari;

3) Terbiasa berprilaku dengan sifat-sifat terpuji, menghindari sifat-sifat tercela, dan bertatakrama dalam kehidupan sehari-hari;

4) Memahami sumber hukum dan ketentuan hukum Islam tentang ibadah, muamalah, mawaris, munakahat, jenazah, dan mampu mengamalkannya dalam kehidupan sehari-hari;

5) Memahami dan mampu mengambil manfaat dan hikmah perkembangan Islam fase Umayah, Abbasiyah, abad pertengahan, abad pembaruan, dan 
perkembangan Islam di Indonesia dan dunia serta mampu menerapkannya dalam kehidupan sehari-hari. ${ }^{10}$

Misalnya: membaca ayat 67 surat Al-Mukmin, menjelaskan makna harfiah dan makna ayat secara lengkap, menyimpulkan isi ayat tersebut, dan bisa mewujudkan perilaku yang mencerminkan isi ayat tersebut.

Menganalisis standar kompetensi berarti melakukan perincian suatu kompetensi menjadi sub-sub kompetensi. Kemudian hasil rincian sub-sub kompetensi tersebut diurutkan. Cara mengurutkannya dapat menggunakan pendekatan prosedural dan hierarkis. ${ }^{11}$

b. Analisis Materi Pembelajaran

Materi pelajaran pendidikan agama Islam merupakan isi atau pesan yang harus dipelajari peserta didik sebagai sarana pencapaian standar kompetensi dan kemampuan dasar yang dinilai dengan menggunakan soal-soal yang disusun berdasar indikator pencapaian belajar. Pokok-pokok materi selanjutnya dirinci atau diuraikan dan diurutkan guna memudahkan kegiatan pembelajaran. Berikut yang perlu diperhatikan dalam merinci atau menguraikan materi PAI. ${ }^{12}$

Konstruk isi bidang studi menurut Reigeluth dan Merril meliputi: fakta, konsep, prinsip, dan prosedur. Fakta ialah asosiasi antara objek atau simbol yang ada atau atau yang mungkin ada dalam lingkungan nyata atau imajinasi; misalnya, Makkah al-Mukarromah sebagai kota suci umat Islam. Konsep ialah sekelompok objek, peristiwa, atau simbol yang memiliki karekteristik umum yang sama dan yang diidentifikasi dengan nama yang sama, misalnya konsep tentang manusia, ibadah, hari akhir, surge, neraka. Prinsip ialah hubungan sebab akibat antarkonsep, misalnya hubungan diciptakannya manusia dengan diperintahkannya ibadah, hubungan perintah shalat dengan pencegahan perbuatan keji dan mungkar. Prosedur ialah urutan langkah untuk mencapai suatu tujuan, memecahkan masalah tertentu, atau membuat sesuatu, misalnya prosedur menetapkan hukum dalam

\footnotetext{
10 Ibid., hal. 149-150

11 Ibid., hal. 149-150

12 Ibid., hal. 151
} 
Islam terhadap suatu masalah. Yang dimana juga harus berdasarkan Al-Qur'an, Hadis, Ijma, dan Qiyas. ${ }^{13}$

Materi pelajaran pula ditentukan jenis dan ruang lingkupnya. Langkah-langkah menentukan jenis dan cakupan materi pelajaran meliputi:

1) Mengidentifikasi atau mengklasaifikasikan apakah materi pelajaran yang akan diajarkan termasuk fakta, konsep, prinsip, prosedur atau gabungan dari beberapa jenis materi pelajaran.

2) Merinci dan menganalisis cakupan atau ruang lingkup materi yang terdapat pada setandar kompetensi, dan kemampuan dasar.

3) Penyajian materi dapat diurutkan dengan menggunakan pendekatan prosedural, heirarkis, dari sederhana ke sukar, dari konkret ke abstrak, spiral, tematis, terpadu, dan sebagainya. ${ }^{14}$

c. Analisis Karakteristik Peserta Didik

Untuk menganalisis karakteristik peserta didik terlebih dahulu menjawab pertanyaan siapa yang belajar, bagaimana tingkat pengetahuan prasyarat, pengetahuan awal, dan karakteristik peserta didik yang diberi pelajaran. Karakteristik perseorangan bisa berupa aspek bakat, motivasi belajar. Hasil analisis berupa daftar yang memuat pengelompokan karakteristik peserta didik yang menjadi sasaran pembelajaran. ${ }^{15}$

Karakteristik kemampuan awal peserta didik dapat dijadikan pijakan dalam pemilihan strategi pembelajran. Kemampuan awal amat penting peranannya dalam meningkatkan kebermaknaan pembelajaran sehingga berdampak memudahkan proses internal berlansung dalam diri peserta didik. ${ }^{16}$ Bruner juga menyarankan peseta didik harus belajar melalui kegiatan mereka sendiri dengan memasukkan konsep-konsep dan prinsip-prinsip dimana mereka harus didorong untuk mempunyai pengalaman dan melakukan eksperimen-eksperimen dan membiarkan mereka untuk menemukan prinsip-prinsip bagi mereka sendiri. ${ }^{17}$

\footnotetext{
${ }^{13}$ Muhaimin, Paradigma Pendidikan .... hal 238.

${ }^{14}$ Maksudin, Pengembangan Metodologi .... hal., 152

15 Ibid., hal. 153

${ }^{16}$ Muhaimin, Paradigma Pendidikan .... hal. 246

${ }^{17}$ Sri Esti Wuryani Djiwandono, Psikologi Pendidikan, (Jakarta: PT Grasindo, 2008), hal. 171
} 
Berikut langkah-langkah analisis kemampuan awal adalah (1) amatilah peserta didik secara perseorangan, bisa menggunakan tes kemampuan awal angket, dan wawancara; tes kemampuan awal untuk mengetahui konsep, prosedur, atau prinsip yang dimiliki. (2) tabulasi karakteristik perseorangan berdasarkan pengamatan awal, keudian diklasifikasi secara rinci; hasil tabulasi digunakan untuk membuat dafatar klasifikasi karakteristik menonjol yang perlu diperhatikan dalam penetapan strategi pengelolaan; dan (3) buatlah daftar karakteristik peserta didik yang selanjutnya untuk menentukan strategi pengelolaan pembelajaran; pembuatan daftar karakteristik harus disesuaikan dengan kemajuan-kemajuan belajar yang dapat dicapai peserta didik. ${ }^{18}$

1) Memilih dan Menetapakan Pendekatan

Pendekatan yang digunakan dalam pembelajaran PAI didasarkan pada target standar kompetensi, kemampuan dasar yang telah ditetapkan. Untuk mencapai target tersebut pendekatan yang digunakan adalah pendekatan terpadu artinya pendekatan yang satu berkaitan erat dengan pendekatan yang lainnya. Pendekatan terpadu meliputi: keimanan, pengamalan, pembiasaan, rasional, emosional, fungsional, dan keteladanan.

a) Pendekatan keimanan

Pendekatan keimanan memberikan peluang kepada peserta didik untuk mengembangkan pemahaman adanya Tuhan sebagai sumber kehidupan makhluk sejagat.

b) Pendekatan pengamalan

Pendekatan pengalaman memberikan kesempatan kepada peserta didik untuk memperaktekkan dan merasakan hasil-hasil pengamalan ibadah dan akhlak dalam menghadapi tugas-tugas dan masalah dalam kehidupan.

c) Pendekatan pembiasaan

Pendekatan ini memberikan kesempatan kepada peserta didik untuk membiasakan sikap dan perilaku baik yang sesuai dengan ajaran Islam dan budaya bangsa dalam menghadapi masalah kehidupan.

${ }^{18}$ Maksudin, Pengembangan Metodologi .... hal. 153 
d) Pendekatan rasional

Pendekatan rasional ini memberikan peranan pada rasio (akal) peserta didik dalam memahami dan membedakan berbagai bahan ajar dalam materi pokok serta kaitannya dengan perilaku yang baik dengan perilaku yang buruk dalam kehidupan duniawi.

e) Pendekatan emosional

Pendekatan ini berupa menggugah perasaan (emosi) peserta didik dalam menghayati perilaku yang sesuai dengan ajaran Islam dan budaya bangsa.

f) Pendekatan fungsional

Pendekatan fungsional adalah menyajikan bentuk semua materi pokok (AlQur'an, keimanan, ibadah/fiqh, akhlak), dari segi manfaatnya bagi peserta didik dalam kehidupan sehari-hari dalam arti luas.

g) Pendekatan keteladanan

Pendekatan keteladanan, misalnya berupa menjadikan figur guru agama dan non-agama serta petugas sekolah lainnya maupun orang tua peserta didik sebagai cermin manusia berkepribadian agama. ${ }^{19}$

2) Pengorganisasian Materi

Materi pokok merupakan bagian dari struktur keilmuan suatu bahan kajian yang dapat berupa bidang ajar, gugus isi, proses, keterampilan, dan/atau pengetian konseptual, yang harus dimiliki dan dikembangkan pada peserta didik. ${ }^{20}$

Ada tiga macam kegiatan pengorganisasian materi pembelajara, yaitu kegiatan perencanaan, pelaksanaan, dan penilaian. Pada hakekatnya pengorganisasian merupakan kegiatan menyiasati proses pembelajaran terhadap unsur-unsur instrumental melalui upaya pengorganisasian secara rasional dan menyeluruh.

Perencanaan pembelajaran terdiri dari perencanaan per satuan waktu dan perencanaan per satuan bahan ajar. Perencanaan per satuan waktu terdiri dari program tahunan dan program smester. Perencanaan per satuan bahan ajar

${ }^{20}$ Diknas," Kompetensi Dasar Mata Pelajaran ...., hal. 155 
dibuat berdasarkan satu kebulatan bahan ajar yang dapat disampaikan dalam satu atau beberapa kali pertemuan. ${ }^{21}$

Pelaksanaan pembelajaran terdiri langkah-langkah pembelajaran di dalam atau di luar kelas, mulai dari pendahuluan, penyajian, dan penutup.

Penilaian pembelajaran merupakan proses yang dilakukan terus menerus sejak perencanaan, pelaksanaan, dan setelah pelaksanaan pembelajaran per pertemuan, satuan bahan ajar, maupun per satuan waktu pertemuan.

Perencanaan dan pelaksanaan pembelajaran didasarkan prinsip-prinsip didaktik, yaitu dimulai dari mudah ke sulit, dari sederhana ke kompleks, dan dari konkret ke abstrak. ${ }^{22}$

3) Menetapkan evaluasi Hasil Pembelajaran

Evaluasi hasil pembelajaran senantiasa di dasarkan pada tiga aspek ketercapaian, yaitu aspek standar kompetensi, aspek kemampuan dasar, dan aspek indikator-indikator yang telah ditetapakan sebelumnya.

Di dalam kurikulum berbasis kompetensi mata pelajaran pendidikan agama Islam (PAI) untuk Sekolah Menengah Umum ada lima unsur pokok mata pelajaran PAI yaitu Al-Qur'an, keimanan, akhlak, fiqh/ibadah, dan tarikh. Kelima unsur tersebut telah dijabarkan satu persatu.

Di samping itu, dari kelima unsur pokok mater PAI telah dijabarkan indikator-indikator atau kompetensi spesifik yang diharapkan dapat dikuasai peserta didik. Indikator-indikator ini dijadikan sebagai terget pencapaian pembelajaran dan sekaligus menjadi ukuran keberhasilan proses pembelajaran PAI.

Rumusan kompetensi dalam indikator berupa kompetensi rasional, sehingga tingkat ketercapaiannya dapat diukur. Misalnya "siswa dapat melaksanakan shalat fardhu".

Pada dasarnya kompetensi dasar dianggap telah dikuasai siswa, jika spesifikasi kompetensi yang menjadi indikator telah dikuasai. Akan tetapi pada kompetensi dasar tertentu ketercapaiannya siukur sesuai dengan apa yang ada dalam indikator saja belum memadai untuk dijadikan petunjuk ketercapaian

${ }^{21}$ Maksudin, Pengembangan Metodologi .... hal. 155

22 Ibid., hal. 155-156 
kompetensi dasar, hal ini disebabkan sulitnya memerinci kompetensi dasar menjadi bentuk perilaku operasional. Misalnya kompetensi dasar beriman. Oleh karena itu, indikator ketercapaian kompetensi dasarnya adalah aspekaspek perilaku lahiriah dari keimanan. ${ }^{23}$

\section{KESIMPULAN}

Hakikat desain pengembangan pembelajaran merupakan kegiatan dalam memilih, menetapkan, dan mengembangkan metode pembelajaran sesuai kondisi yang ada untuk mencapai hasil yang diharapkan. Desain pengembangan pembelajaran PAI dengan menggunakan model Kemp berpijak pada empat unsur dasar perencanaan pembelajaran, yaitu peserta didik, tujuan, metode, dan evaluasi. Model desain pengembangan Dick dan Carey mengacu pada pendekatan sistem (system approach) dan model desain pengembangan Degeng didasarkan pada variabel yang memengaruhi pembelajaran berupa tujuan dan karekteristik bidang studi, sumber belajar dan kendala, karakteristik peserta didik, tujuan belajar dan isi pembelajaran, strategi pengorganisasian isi pembelajaran, strategi penyampaian isi pembelajaran, strategi pengelolaan pembelajaran, pengembangan prosedur pengukuran hasil pembelajaran. Langkah-langkah desain pengembangan pembelajaran PAI di sekolah dan madrasah antara lain: analisis strandar kompetensi, materi pembelajaran, karakteristik peserta didik, memilih dan menetapkan pendekatan dan menetapkan evaluasi hasil pembelajaran.

\section{DAFTAR PUSTAKA}

Diknas," Kompetensi Dasar Mata Pelajaran Pendidikan Agama Islam SMU” dalam Maksudin, Pengembangan Metodologi Pendidikan Agama Islam Pendekatan Dialektik, Yogyakarta: Pustaka Pelajar, 2015

Djiwandono, Sri Esti Wuryani. Psikologi Pendidikan. Jakarta: PT Grasindo, 2008

Maksudin. Pengembangan Metodologi Pendidikan Agama Islam Pendekatan Dialektik. Yogyakarta: Pustaka Pelajar, 2015

Muhaimin. Paradigma Pendidikan Islam: Upaya Mengefektifkean Pendidikan Agama Islam di Sekolah. Bandung: PT. Remaja Rosdakarya, 2004

Trianto. Mendesain Model Pebelajaran Inovatif-Progresif: Konsep, Landasan, dan Implementasinya pada Kurikulum Tingkat Satuan Pendidikan (KTSP). Jakarta: Kencana, 2010

${ }^{23}$ Ibid., hal. 156 